\begin{tabular}{|c|l|}
\hline Title & Physical-Chemical Basis of Injury from Intracellular Freezing in Y east \\
\hline Author(s) & Mazur, Peter \\
\hline Citation & Cellular Injury and Resistance in Freezing Organisms : proceedings, 2, 171-189 \\
\hline Issue Date & 1967 \\
\hline Doc URL & http:/hdl.handle.net/2115/20416 \\
\hline Type & bulletin (article) \\
\hline Note & $\begin{array}{l}\text { International Conference on Low Temperature Science. I. Conference on Physics of Snow and Ice, II. Conference on } \\
\text { Cryobiology. (A ugust, 14 19, 1966, Sapporo, Japan) }\end{array}$ \\
\hline File Information & \begin{tabular}{l} 
1_p171-189.pdf \\
\hline
\end{tabular} \\
\hline
\end{tabular}

Instructions for use 


\title{
Physical-Chemical Basis of Injury from Intracellular Freezing in Yeast*
}

\author{
Peter MAZUR \\ Biology Division, Oak Ridge National Laboratory, Oak Ridge, Tennessee, U.S.A.
}

\begin{abstract}
The death of cells of Saccharomyces cerevisiae cooled at rates above $1-10^{\circ} \mathrm{C} / \mathrm{min}$ is correlated with the formation of ice crystals within the cells. This view is based on the following evidence: (1) The cooling rates that produce death coincide with those that cause intracellular water to become supercooled; (2) The volume of rapidly cooled cells is much larger than it would be if they contained no ice; (3) Alternative hypotheses do not account for the observed data. Cells that are killed under conditions yielding intracellular ice show extensive permeability damage immediately after thawing. Evidence is presented to support the view that intracellular freezing is a cause of death and not a consequence of death from some other cause. This view is based chiefly on the observation that survival is proportional to warming velocity. Two explanations for the lethal action of intracellular freezing are discussed. One is that injury is due to the removal of water by intracellular ice; the other is that injury is associated with the tendency of ice crystals to attain a minimum surface energy (i.e., a maximum radius of curvature). The evidence with yeast favors the latter.
\end{abstract}

\section{Introduction}

Although the response of cells and tissues to subzero temperatures has been studied many years, the fundamental causes of injury still remain obscure. Part of the difficulty is that cells are subjected to at least four concurrent phenomena during low temperature exposure, any one of which could lead to irreversible injury. The four phenomena are (1) lowered temperature itself, (2) the formation of ice crystals, (3) the increase in solute concentration produced by ice crystal formation, and (4) the removal of liquid water by its conversion to ice. To arrive at the cause or causes of injury one must first determine the relative contributions of each of the four phenomena to injury. Unfortunately the dissection is not simple and, therefore, has not been carried out in many instances.

Another complication is that the phenomenological cause of injury depends on the specific conditions under which a specific cell is exposed to low temperatures. Consider two examples: Log phase cells of Escherichia coli are extremely susceptible to injury from rapid chilling to near $0^{\circ} \mathrm{C}$, whereas stationary phase cells are insensitive (Meynell, 1958). Slowly frozen red cells appear to be injured by the high concentrations of intraand extracellular electrolytes attained during freezing, but very rapidly frozen red cells appear to be injured by intracellular ice formation (Gehenio et al., 1963; Rapatz et al., , 1963 ; Luyet et al., 1963 ; Mazur, 1965 a).

* Research sponsored by the U.S. Atomic Energy Commission under contract with Union Carbide Corporation. 
Still another complication is to distinguish the effects of those phenomena occurring within cells from those occurring outside of them. When the extracellular medium freezes, most of the cell water must eventually freeze to maintain thermodynamic equilibrium across the cell membrane, but it does not necessarily have to freeze within the cell. When cooling is sufficiently slow, intracellular unfrozen water will flow out of the cell in response to any vapor pressure gradient and freeze externally (Mazur, $1963 \mathrm{~b}$ ). On the other hand, if cooling is rapid, some of the intracellular water will freeze within the cell, usually with lethal results.

Although factors associated with injury have been identified in some cases, the exact relations between any one factor and cell death remain unknown. Some cells are killed by exposure to the concentration of solutes that occurs during freezing, but the mechanisms by which the concentrated solutes lead to death are not known. Most cells are killed when they freeze internally, but the nature of the lethal injury inflicted by intracellular ice is unknown.

Freezing injury in yeast appears to be due to either the concentration of solutes or to intracellular freezing, or to a combination of both.

The general effects of subzero temperatures are illustrated in Fig. 1. Survival can be seen to be dependent on the minimum temperature to which the cells are cooled and on the rate at which they are cooled and warmed. Lowering the temperature from -5 to $-30^{\circ} \mathrm{C}$ always kills at least half of the cells, regardless of the cooling or warming rate employed; but the sequence of rapid cooling and slow warming produces much more extensive mortality than the reciprocal sequence of slow cooling and rapid warming. The cause of death of the $50 \%$ that are killed by the sequence of slow cooling to below

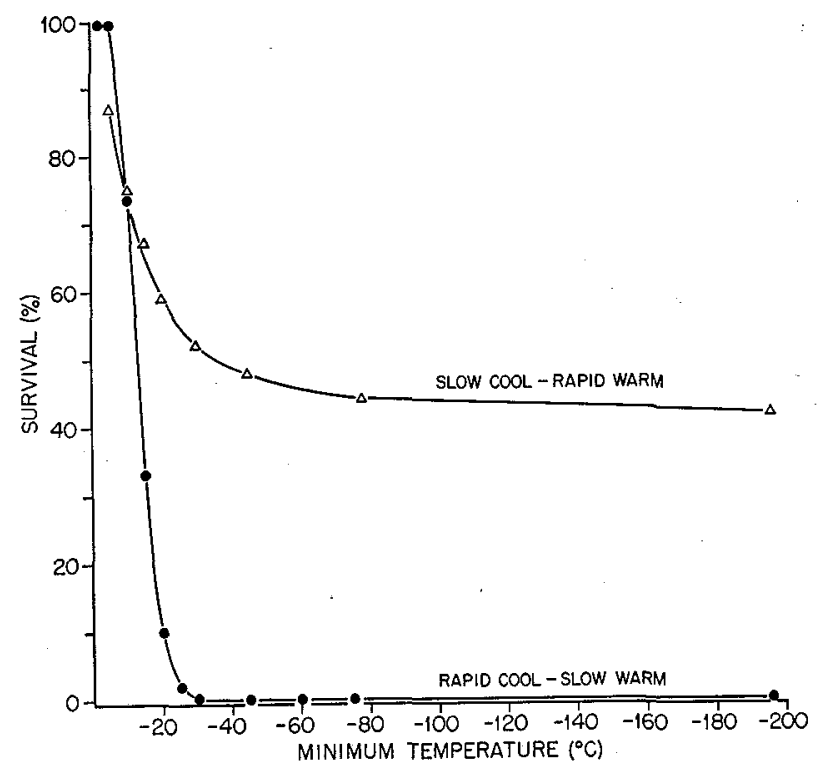

Fig. 1. Survival of yeast as a function of temperature. Cells were suspended in distilled water, cooled to various temperatures at $1^{\circ} \mathrm{C} / \mathrm{min}$ (slow cooling) or $50^{\circ} \mathrm{C} / \mathrm{min}$ (rapid cooling) and warmed at $1^{\circ} \mathrm{C} / \mathrm{min}$ (slow warming) or 500 to $1400^{\circ} \mathrm{C} / \mathrm{min}$ (rapid warming) 
$-30^{\circ} \mathrm{C}$ and rapid warming is uncertain. The injury is known to be associated with the formation of ice, for none occurs in suspensions supercooled to as low as $-15^{\circ} \mathrm{C}$ (Mazur, 1961 a), and it may be due to deleterious action from concentrated solutes. However, a good deal more is known about the factor responsible for the much greater lethality produced by the sequence of rapid cooling and slow warming; the evidence indicates that the lethal factor is intracellular freezing.

The purpose of the present paper is to examine the role of intracellular ice formation in the low-temperature injury of cells of the yeast Saccharomyces cerevisiae. The discussion will first consider the evidence that a major fraction of injury is closely correlated with internal freezing. It will then take up the question of whether intracellular freezing is a cause of this injury, or merely the result of injury by some other agent. The conclusion is reached that the injury is, in fact, caused by internal ice formation; hence, the last part of the discussion will evaluate the available evidence bearing on the mechanism by which it leads to death.

\section{Relation between Injury and Intracellular Ice Formation in Yeast}

One of the major lines of evidence connecting death to intracellular freezing is summarized in Fig. 2. The solid curves show the relation between survival and the rate at which cells were cooled to $-70^{\circ} \mathrm{C}$. After reaching $-70^{\circ} \mathrm{C}$, the cells were then cooled rapidly to $-196^{\circ} \mathrm{C}$ and either warmed ultra-rapidly at $40,000^{\circ} \mathrm{C} / \mathrm{min}$, rapidly at $1400^{\circ} \mathrm{C} / \mathrm{min}$, or slowly at $1^{\circ} \mathrm{C} / \mathrm{min}$. With the two lower warming rates, an abrupt drop in survival is noted when the cooling velocity exceeds $10^{\circ} \mathrm{C} / \mathrm{min}$. The reasons for believing that the

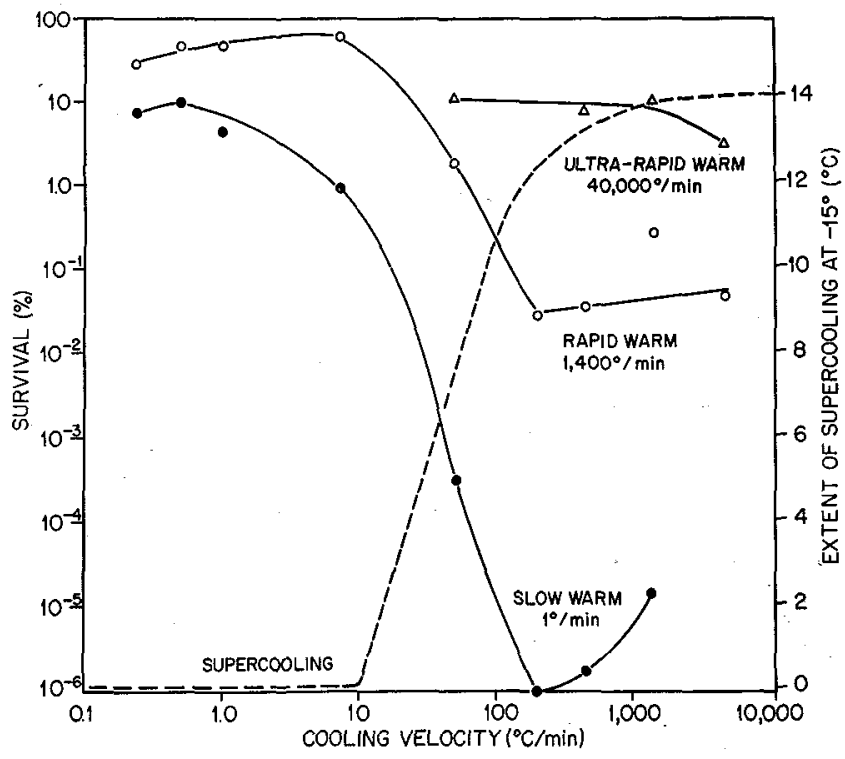

Fig. 2. Survival and supercooling of Saccharomyces cerevisiae as a function of cooling velocity. Cells were suspended in triple distilled water, cooled at various rates to $-70^{\circ} \mathrm{C}$, transferred to liquid nitrogen, and warmed at the rates indicated. The supercooling curve was derived from the calculated curves in Fig. 3 
drop is associated with intracellular freezing are the following:

A. Whenever cells have been observed during freezing, the surrounding aqueous environment has been found to freeze before the cells themselves. In fact, most cells remain unfrozen at temperatures above about $-10^{\circ} \mathrm{C}$, even when the water around them is frozen (Mazur, $1965 \mathrm{~b}$ ). The internal osmolarity of cells is usually below 1. Accordingly, the equilibrium freezing point of cell contents is above $-2^{\circ} \mathrm{C}$, and the water in an unfrozen cell at any temperature below $-2^{\circ} \mathrm{C}$ must be supercooled. Thermodynamic equilibrium can be restored in one of two ways. (1) The supercooled intracellular water can freeze in situ or (2) it can flow out of the cell in sufficient quantity to reduce the vapor pressure of the internal water to that of ice by concentrating the intracellular solutes.

A second-order differential equation describing the second process has been derived elsewhere (Mazur, $1963 \mathrm{~b}$ ). This equation gives the volume of water remaining in a cell at various subzero temperatures, providing one knows the cooling velocity and a number of characteristics of the cell; namely, its surface to volume ratio, its permeability to water, the temperature coefficient of the permeability, and the osmoles of intracellular solute. Numerical solutions of the equation applicable to $S$. cerevisiae are shown in Fig. 3 . The plot shows the calculated percentage of the normal water content remaining in the cells as cooling progresses at the indicated rates. The equilibrium curve shows what the water content has to be to maintain vapor pressure equilibrium with the external ice. The faster the cells are cooled, the more their water content departs from the equilibrium

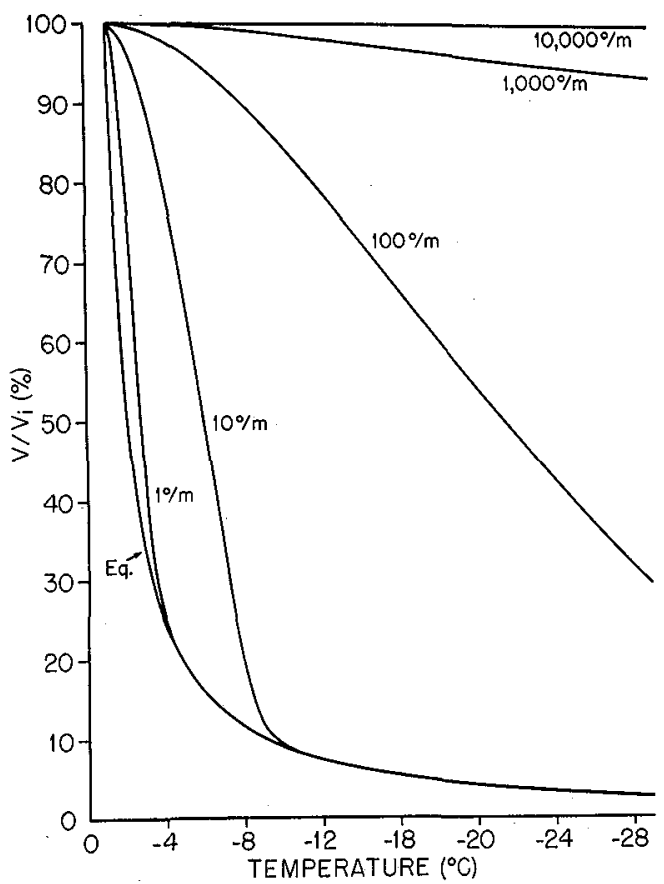

Fig. 3. Calculated percentages of intracellular water $\left(V / V_{i}\right)$ remaining in yeast cells as a function of temperature and cooling velocity. The curve $E_{q}$ represents the equilibrium water content (from Mazur, 1965 a) 
value for a given temperature, and the more the water is supercooled. The number of degrees it is supercooled at any given temperature is the number of degrees between the point on a given curve above that temperature and the point on the equilibrium curve corresponding to the same water content. The extent of supercooling at $-15^{\circ} \mathrm{C}$ is shown by the dotted curve in Fig. 2 for cells cooled at various rates. When they are cooled at $10^{\circ} \mathrm{C} / \mathrm{min}$ or slower, they contain no supercooled water (in other words they dehydrate to the equilibrium water content before their temperature has dropped to $-15^{\circ} \mathrm{C}$ ); but when they are cooled at more than $10^{\circ} \mathrm{C} / \mathrm{min}$, the cell water begins to be supercooled, and the number of degrees it is supercooled rises sharply as the cooling velocity rises.

The cooling velocities at which the intracellular water is calculated to become supercooled $\left(10-100^{\circ} \mathrm{C} / \mathrm{min}\right)$ are seen to coincide closely with the cooling velocities at which survival abruptly drops. This coincidence strongly suggests that the drop in survival is a reflection of the freezing of the water, since the probability of freezing rises exponentially with the extent of supercooling (Mazur, $1966 \mathrm{~b}$ ). This conclusion could be stated in opposite terms; namely the high survival of cells cooled at rates lower than $10^{\circ} \mathrm{C} / \mathrm{min}$ is due to the fact that these low rates permit the cells to equilibrate with the external ice by dehydration. The cytoplasm of an equilibrated cell remains at its freezing point and, therefore, cannot freeze.

B. The conclusions from these calculations have been supported by measurements of the volumes of cells and of the total fraction of cell water frozen in cells cooled at various rates. Wood and Rosenberg (1957) and Souzu, Nei and Bito (1961) made calorimetric measurements of the fraction of cell water that freezes at various temperatures, and Mazur (1963 a) made measurements by differential thermal analysis. Both techniques indicated that some $80-90 \%$ of the cell water is frozen below $-20^{\circ} \mathrm{C}$; but it could not be determined by either method whether the cell water froze in the cell, or outside the cell. However, the site of freezing can be determined if one knows the volume of cells after they are cooled. The photomicrographs in Fig. 4 show yeast cells cooled at 1 or $280^{\circ} \mathrm{C} / \mathrm{min}$ to $-79^{\circ} \mathrm{C}$ and fixed at that temperature by freeze-substitution. The cells cooled at $1^{\circ} \mathrm{C} / \mathrm{min}$ are obviously shrunken and distorted. Those cooled at $280^{\circ} \mathrm{C} / \mathrm{min}$ are also smaller than the normal cells shown in the top photomicrograph, but they are considerably larger than the cells cooled at $1^{\circ} \mathrm{C} / \mathrm{min}$. The measured volumes of variously treated cells are listed in Table 1 . The volume of untreated cells was $135 \mu^{3}$, of which $80 \%$ or $108 \mu^{3}$ is water (Wood and Rosenberg, 1957; Souzu et al., 1961 ; Mazur, 1963 a). About $90 \%$ of that, or $97 \mu^{3}$, is freezable. If all the freezable water left the cell and froze externally, the cell volume should be $135-97$, or $38 \mu^{3}$; and this is close to the observed volume of slowly cooled freeze-substituted cells $\left(35-41 \mu^{3}\right)$. On the other hand the volume of rapidly cooled freeze-substituted cells was 58 to $67 \mu^{3}$, values that indicate that about 20 to $29 \mu^{3}$ of the freezable cell water froze intracellularly. Two assumptions underlie these conclusions. One is that the volumes of the frozen cells remained unchanged both during freeze-substitution in ethanol and after warming to room temperature for observation. This assumption is probably valid, for numerous comparisons between freezesubstituted cells of various sorts and those fixed by other methods have not shown differences in size or shapes of the cells ( $c f$. , Rapatz, Nath and Luyet, 1963, Fig. 4). 


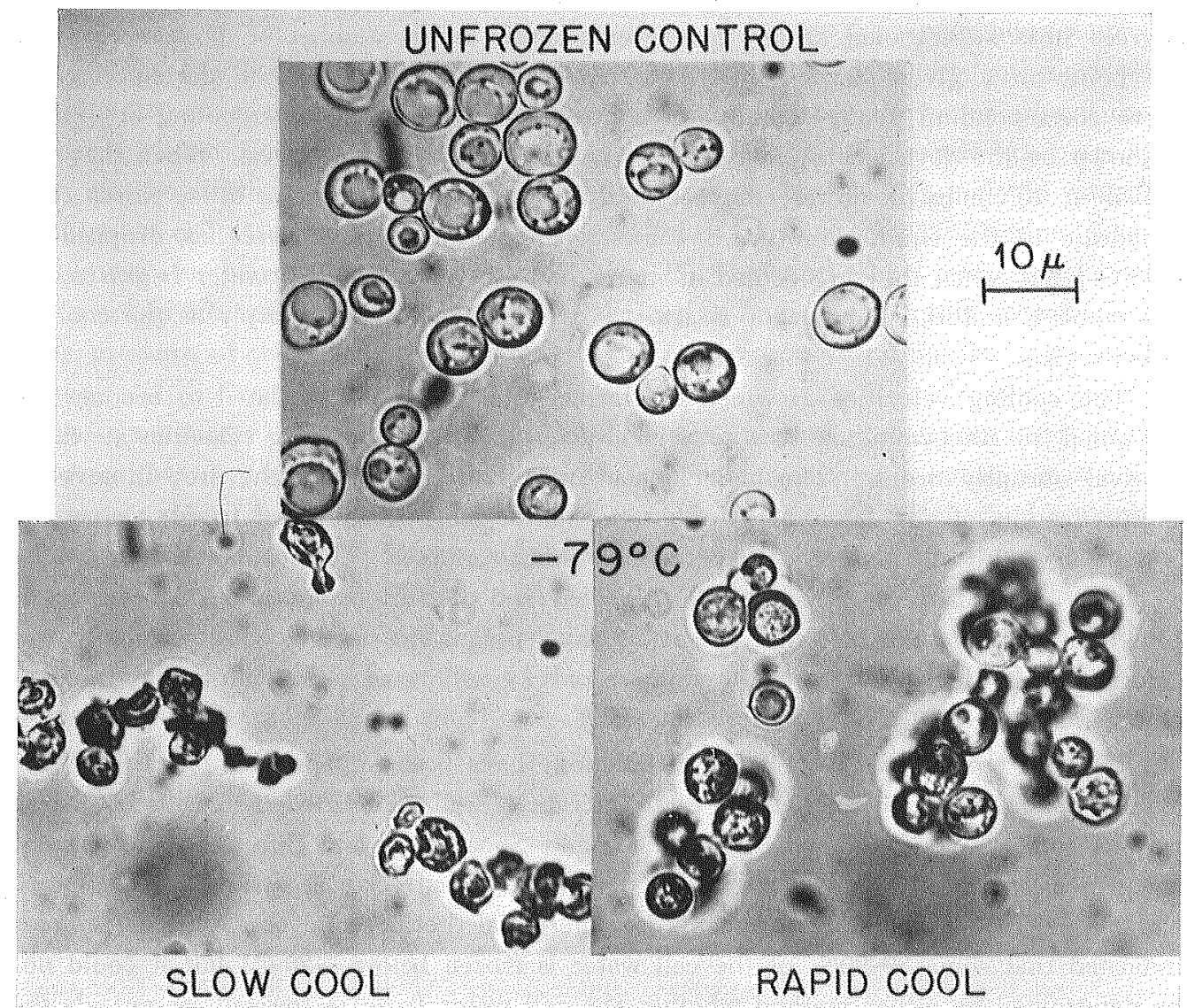

Fig. 4. Appearance of untreated yeast and of yeast cooled rapidly or slowly to $-79^{\circ} \mathrm{C}$ and fixed at that temperature by substitution with cold ethanol (from Mazur, 1961 b)

Table 1. Dimensions of yeast cells cooled rapidly or slowly to $-32,-65$ or $-79^{\circ} \mathrm{C}$ and fixed at these temperatures by freeze-substitution with ethanol

\begin{tabular}{ccc}
\hline $\begin{array}{c}\text { Temp. during substitution } \\
\left({ }^{\circ} \mathrm{C}\right)\end{array}$ & $\begin{array}{c}\text { Cooling velocity } \\
\left({ }^{\circ} \mathrm{C} / \mathrm{min}\right)\end{array}$ & $\begin{array}{c}\text { Avg. cell volume } \\
\left(\mu^{3}\right)\end{array}$ \\
\hline \multirow{2}{*}{-32} & 1 & 41.2 \\
& 50 & 58.9 \\
\hline \multirow{2}{*}{65} & 1 & 38.5 \\
& 200 & 66.6 \\
\hline \multirow{2}{*}{-79} & 1 & 35.1 \\
& 280 & 58.4 \\
\hline
\end{tabular}

Modified from Mazur (1961 b) 
Furthermore, Nei (1960) has directly observed, with the microscope, that slowly cooled yeast cells shrink more than rapidly cooled cells even in the absence of freeze-substitution or any other form of fixation. The second assumption is that all of the volume change can be accounted for in terms of changes in the water content of the cells. One alternative possibility is that shrinkage of the cell is partly due to loss of solutes during freezing, but the results of electrical resistance measurements argue against this (Mazur, 1963 a). Another possibility is that the volume of a cell decreases by less than the volume of the water that leaves it; but if this occurred, bubbles or vacuoles would have formed inside the cells.

C. The correspondence between the cooling rates that produce a drop in survival and those that are calculated to produce supercooled water, and the measurements of the volumes of cells after slow or rapid cooling provide the most direct evidence for the conclusion that injury is associated with intracellular freezing. However, there is additional circumstantial evidence: (a) As already noted, slow cooling at $1^{\circ} \mathrm{C} / \mathrm{min}$ to $-70^{\circ} \mathrm{C}$ yields about $50 \%$ survival; but Fig. 5 shows that cooling has to be carried out slowly only down to $-20^{\circ} \mathrm{C}$ in order to achieve maximal protection. In other words, cells that are cooled at $1^{\circ} \mathrm{C} / \mathrm{min}$ to $-20^{\circ} \mathrm{C}$ and then cooled rapidly to $-196^{\circ} \mathrm{C}$ show just as high percent survival as cells cooled at $1^{\circ} \mathrm{C} / \mathrm{min}$ to $-70^{\circ} \mathrm{C}$ and then cooled rapidly to $-196^{\circ} \mathrm{C}$. Comparable results were reported earlier by Araki and Nei (1962). These findings are consistent with the view that slow cooling at $1^{\circ} \mathrm{C} / \mathrm{min}$ protects by preventing intracellular freezing. Mention was made of the fact that calorimetric measurements show that

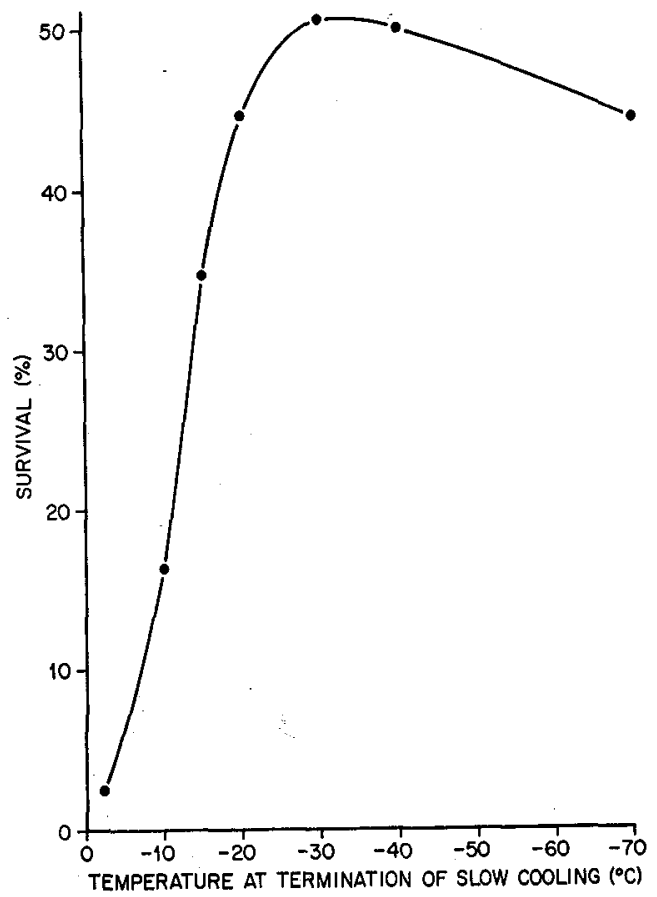

Fig. 5. Percentage survival of yeast cells cooled slowly to the indicated temperature and then rapidly to $-196^{\circ} \mathrm{C}$. Subsequent warming was rapid 
practically all the freezable cell water is frozen below $-20^{\circ} \mathrm{C}$. If slow cooling permits this water to leave the cell and freeze externally, then nearly all the freezable water will have left the cell by the time the temperature has dropped to $-20^{\circ} \mathrm{C}$, and little or no intracellular freezing can occur at lower temperatures, even if subsequent cooling is rapid. (b) A number of other observations on yeast are consistent with the view that injury is associated with the formation of intracellular ice, and some of these observations are inconsistent with alternative hypotheses. (1) As shown in Fig. 1, when yeast are cooled rapidly to various temperatures, survival drops abruptly from $100 \%$ at $-5^{\circ} \mathrm{C}$ to about $10 \%$ at $-20^{\circ} \mathrm{C}$, provided the suspending medium is frozen. In contrast, if the suspending medium is supercooled, $100 \%$ of the cells survive to temperatures as low as $-15^{\circ} \mathrm{C}$, the lowest temperature at which suspensions have remained unfrozen (Mazur, 1961 a ; Araki and Nei, 1962). This finding clearly indicates that lethality is not due to lowered temperature itself, but is dependent on ice formation, in the medium or in the cells.

(2) The fact that $100 \%$ of cells survive contact with ice at $-5^{\circ} \mathrm{C}$ or above suggests that injury is not due to mechanical effects of extracellular ice. Furthermore, $50-60 \%$ of the cells survive cooling to as low as $-196^{\circ} \mathrm{C}$ if cooling is slow and warming rapid, and some $10 \%$ of the cells survive rapid cooling to $-19^{\circ} \mathrm{C}$ if warming is ultra-rapid (Fig. 2). These findings indicate that whatever mechanical stresses are induced by the formation of extracellular ice under these conditions, they are much less injurious than the stresses produced by cooling at moderate rates $\left(50^{\circ} \mathrm{C} / \mathrm{min}\right)$ to say $-75^{\circ} \mathrm{C}$ and warming slowly at $1^{\circ} \mathrm{C} / \mathrm{min}$, a treatment that yields $0.01 \%$ survival or less.

(3) The fact that slow cooling is less injurious than rapid is inconsistent with ascribing injury to exposure to concentrating solutes, since the slower the cooling, the longer the exposure. This conclusion is buttressed by experiments in which injury is followed as a function of time at a given subzero temperature. When cells were rapidly cooled to $-30^{\circ} \mathrm{C}$, held for various lengths of time, and then warmed rapidly, survivals were almost the same after $1 \mathrm{~min}$ exposure at $-30^{\circ} \mathrm{C}(1.5 \%)$ as after $90 \mathrm{~min}$ exposure $(0.9 \%)$ (Mazur, 1961 a). Araki and Nei (1962) similarly observed that survivals dropped rapidly in the first few minutes of exposure, and then much more slowly.

\section{Intracellular Freezing as a Causal Agent in Lethal Injury to Yeast}

It is generally assumed that whenever intracellular ice forms in a cell, the cell is immediately killed (Asahina, 1965) ; therefore, it has usually been concluded that the injury is a direct consequence of ice formation. Several investigators, however, have reported findings that challenge the universality of this conclusion.

Sherman (1962) reported that frozen-thawed mouse skin and parakeet tumors remained viable even though intracellular ice was visible in every cell. The criterion of intracellular ice was the presence of lacunae in cells fixed by freeze-drying. The criterion of viability was the ability of frozen and thawed skin or tumor to grow upon transplantation. The difficulty with this method of assessing survival is to know what percentage of cells was viable, and whether this percentage did in fact contain ice crystals.

Asahina (1962) suggests that in one species of sea urchin eggs, Hemicentrotus pulcherrimus, intracellular freezing is not the cause of injury, but, rather is the result of prior 
irreversible injury caused by precipitation of salts at their eutectic point. He found that the lethal temperature for these eggs correlated well with the eutectic point of the suspending medium. For example, when the eggs were suspended in a $\mathrm{KNO}_{3}$ solution (eutectic point, $-2.8^{\circ} \mathrm{C}$ ), $90 \%$ survived cooling to $-2.5^{\circ} \mathrm{C}$ but none survived cooling to $-5^{\circ} \mathrm{C}$. On the other hand, in a $\mathrm{NaCl}$ solution (eutectic point, $-21.1^{\circ} \mathrm{C}$ ), $90 \%$ survived cooling to $-25^{\circ} \mathrm{C}$ but only $3 \%$ survived cooling to $-30^{\circ} \mathrm{C}^{*}$. Microscopic observations of eggs in $\mathrm{KNO}_{3}$ showed that the precipitation of salts at $-4^{\circ} \mathrm{C}$ was followed by a wave of intracellular freezing. But intracellular freezing did not occur at $-4^{\circ} \mathrm{C}$ when eggs were suspended in solutions with eutectic points below $-4^{\circ} \mathrm{C}$. Asahina suggests that the dehydration occurring at the eutectic point damaged the cell membrane in such a way as to allow intracellular freezing to occur.

This pattern was not observed in the egg of another species of sea urchin, Strongylocentrotus nudus (Asahina, 1961). When that organism was cooled at $5-9^{\circ} \mathrm{C} / \mathrm{min}$, it underwent intracellular freezing at $-8^{\circ} \mathrm{C}$, which is more than $12^{\circ} \mathrm{C}$ above the eutectic point of the sea water in which it was suspended.

In the yeast Saccharomyces cerevisiae, I believe the evidence strongly favors the idea that intracellular freezing is a direct cause of injury rather than the consequence of injury by some other agent. The evidence is the following:

A. Unlike the situation with Hemicentrotus pulcherrimus, the lethal temperature range for S. cerevisiae is unrelated to the eutectic point of the suspending medium. Survival drops abruptly between -10 and $-20^{\circ} \mathrm{C}$ regardless of whether the cells are suspended in triple distilled water, or in $0.1 \mathrm{M}$ solutions of $\mathrm{KH}_{2} \mathrm{PO}_{4}, \mathrm{NaCl}$ or $\mathrm{CaCl}_{2}$ with eutectic points of $-2.7,-21.1$ and $-50^{\circ} \mathrm{C}$, respectively (Mazur, $1961 \mathrm{a}$ ).

B. It has already been pointed out that the cooling rates above which massive death occurs coincide with the cooling velocities which result in the formation of intracellular ice. If the drop in survival at higher cooling rates is caused by a factor other than intracellular freezing, one has to conceive of a factor the lethality of which is similarly correlated with cooling velocity. The only other factor that has been reported to be more injurious at higher cooling rates than at low rates is thermal shock, the injury observed in some organisms when they are cooled to near $0^{\circ} \mathrm{C}$ (Smith, 1961). However we have already seen that yeast are not injured by rapid cooling to as low as $-15^{\circ} \mathrm{C}$ as long as the suspensions remain unfrozen.

C. Figure 2 shows that the faster yeast cells are cooled, the more their survival becomes dependent on warming velocity. For example, when the cells are cooled at $400^{\circ} \mathrm{C} / \mathrm{min}$, the percentages of survival after warming at 1,1400 and $40,000^{\circ} \mathrm{C} / \mathrm{min}$ are $10^{-6}, 3 \times 10^{-2}$ and $10 \%$, respectively. The lethality of the factor that is responsible for injury is, therefore, dramatically influenced by warming velocity as well as by cooling velocity. We shall see in the next section that the hypothesis that intracellular freezing is directly responsible for injury is consistent with the dependence on warming rate. All other factors that have been suggested as lethal agents are inconsistent.

* Although the eutectic point of a $\mathrm{NaCl}$ solution is $-21.1^{\circ} \mathrm{C}$, complete solidification during cooling does not occur until about -27 to $-30^{\circ} \mathrm{C}$, owing to supersaturation (Rey, 1960; Mazur, $1961 \mathrm{a}$; Greaves and Davies, 1965). 


\section{The Mechanism of Injury by Intracellular Freezing}

Two categories of hypotheses have been advanced to account for the lethality of intracellular freezing, one chemical and one physical. The "chemical" hypothesis is that injury from intracellular freezing is associated with the removal of intracellular water by its deposition as ice. The "physical" hypothesis is that injury results from trauma induced by the ice crystals themselves.

\section{A. WATER REMOVAL AS THE CAUSE OF LETHALITY FROM INTRACELLULAR FREEZING}

When an aqueous solution freezes, be it a simple salt solution or cytoplasm, pure ice precipitates out, and the amount of liquid water decreases with temperature. For any given solution of a given concentration at constant pressure, the fraction of unfrozen water is determined solely, by temperature. For an ideal solution, the fraction $(q)$ is

$$
q \approx-\frac{1.86 \nu m_{i}}{t}
$$

where 1.86 is the molal freezing point depression for water, $\nu$ the number of ionic species into which a solute dissociates, $m_{i}$ the molal concentration of solutes in the solution before freezing, and $t$ the temperature in ${ }^{\circ} \mathrm{C}$ (Mazur, 1963 a). For most mammalian cells, $\nu m_{i}$ (the osmolality of the cytoplasm) is about 0.3 , so that $q \approx 0.56 / t$. For yeast, $\nu m_{i}=0.5$, and $q \approx 0.93 / t$. It follows from this equation that at $-5,-10$ and $-15^{\circ} \mathrm{C}$, the percentages of unfrozen water in yeast would be approximately 18,9 and $6 \%$.

There are a number of conceivable reasons why reducing the fraction of liquid water might be lethal to cells. Levitt (1962), for example, has suggested that as the liquid water content of cells is reduced, structural proteins come in increasingly close contact. If they come sufficiently close, they may become covalently linked by the conversion of sulfhydryl groups into disulfide bonds. Then, when the cell becomes rehydrated during warming, the linked proteins cannot revert to their original conformation, or may become denatured in attempting to do so.

Aside from the question of the specific mechanisms by which dehydration might lead to death, the hypothesis that dehydration is responsible for the lethality of intracellular freezing seems unacceptable for any cell that survives slow cooling but does not survive rapid cooling. Furthermore, it seems difficult for any such hypothesis to account for slow warming being much more deleterious than rapid. Since both of these findings apply to yeast, the dehydration hypothesis does not appear to account for the lethality of intracellular freezing in that organism. The reasons are as follows:

As indicated in eq. (1), the fraction of the initial water content that remains liquid in a given cell in thermodynamic equilibrium with its surroundings depends only on its temperature. The fraction is independent of the rate of cooling to that temperature, and independent of whether the intracellular water freezes in the cell or leaves the cell and freezes externally. We have already seen that when yeast are cooled slowly, the cell water freezes outside the cell and survival is high, and that when the cells are cooled rapidly, the cell water freezes inside the cell and survival is low. Yet in both cases the fraction of unfrozen water in the cells should be equal, and this equality has been 
confirmed by the calorimetric determinations referred to.

To account for the differences in survival after slow and rapid cooling in terms of lowered cell water content, one would have to hypothesize that rapid conversion of water to ice is more deleterious than slow conversion. But then one is faced with the problem of accounting for the opposite effect of warming rate; that is, one has to explain why slow warming (which produces slow rehydration) is so much more detrimental than rapid warming (which produces rapid rehydration). Furthermore, it is known that $96 \%$ of the cell water can be removed from yeast by air drying without producing appreciable loss of viability or enzymatic function (Sant and Peterson, 1958). Why then should freezing be lethal when it only converts some $80-90 \%$ of the cell water into ice?

B. ICE CRYSTALS AS CAUSES OF DAMAGE FROM INTRACELLULAR FREEZING

An alternative explanation of damage from intracellular freezing is that it is due to physical consequences of the ice crystals themselves. In the case of yeast, we must further hypothesize that the damage is not entirely due to the formation of ice crystals during cooling; rather, it must be due, in part, to events occurring during warming. The basis for this statement is the observation noted in Fig. 2 that when the cells are cooled at rates sufficiently high to induce intracellular freezing, survival is found to be highly dependent on warming velocity. This point is amplified by the curves in Fig. 6.

There are indications in the literature that ice crystals that form in cells tend to grow along the more fluid cytoplasmic channels bounded by the structural proteins of

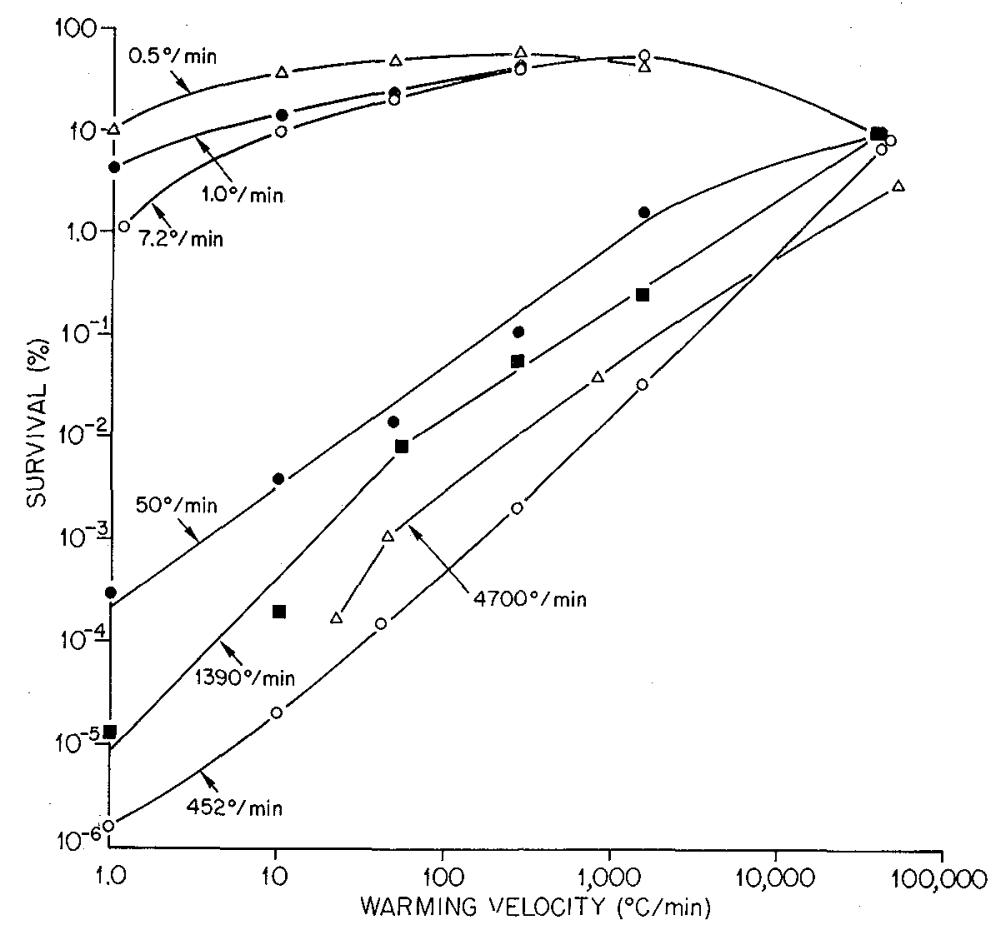

Fig. 6. Survival of the yeast Saccharomyces cerevisiae as a function of warming velocity. Cells were suspended in distilled water, cooled to $-196^{\circ} \mathrm{C}$ at the rates noted alongside the individual curves, and warmed at various rates 
the cell. This is perhaps most clearly seen in the freezing of muscle fibers. According to the older observations of Chambers and Hale (1932) and the more recent observation of Rapatz and Luyet (1959 b), ice crystal growth proceeds preferentially along the long axis of a muscle fiber.

This behavior is to be expected. An ice crystal grows by converting fiquid water to solid. If the growing crystal comes up against a nonaqueous component, it ought, under ordinary circumstances, merely to stop growing in that direction. There would appear to be only two sources of energy by which the crystal could exert force on the nonaqueous component. One source would be pressure from the $10 \%$ increase in volume during freezing; the other source would be the free energy difference between the ice crystal and supercooled water elsewhere in the cell. Presumably, the ice crystal will grow in that direction which minimizes the force. In other words, the crystal will tend to grow through the aqueous portions of the protoplasm rather than exert a disruptive force against membranes and other structural components.

An ice crystal will be most stable (i.e., have minimal surface free energy) when its surface is planar (infinite radius of curvature) (Mazur, $1966 \mathrm{~b}$ ). Regions of positive curvature will have their vapor pressure raised and regions of negative curvature will have their vapor pressure lowered in accordance with the Kelvin equation

$$
\ln \left(\frac{p_{c}}{p_{\infty}}\right)=\frac{2 v \sigma}{r R T}
$$

where $p_{c}$ and $p_{\infty}$ are the vapor pressures of water over a curved ice surface and a plane surface, respectively, $v$ is the molar volume of ice, $\sigma$ the interfacial tension between ice and water, $r$ the radius of curvature of the ice, $R$ the gas constant, and $T$ the temperature in degrees Kelvin. Water molecules will tend to move away from the convex surfaces and into the concave depressions. However, the approach to a surface with a large absolute radius of curvature in cells may be at odds with the structural restrictions imposed by the membranous components of the cell. I would like to suggest that it may be this conflict that is responsible for the injurious effects of intracellular freezing, particularly when it is followed by slow warming.

The basis of the argument can be seen by reference to Fig. 7, which depicts an hour-glass-shaped intracellular membrane forming two compartments, $L$ and $R$, filled with cytoplasm and connected by a narrow annulus. Consider what happens to the compartments and the water in them under three situations.

(1) If cooling is sufficiently slow (less than $10^{\circ} \mathrm{C} / \mathrm{min}$ with yeast), the supercooled water in $L$ and $R$ (and elsewhere in the cell) will flow out of the cell in response to the vapor pressure difference between supercooled water and the external ice (Fig. 7a). This case has already been discussed; it results in the extracellular freezing of the cell water and high survivals.

(2) If cooling is more rapid than $10^{\circ} \mathrm{C} / \mathrm{min}$, intracellular freezing will occur. Suppose that $L$ freezes but $R$ remains supercooled. The vapor pressure of $L$ will immediately be lowered to that of the external ice, and the vapor pressure in $R$ will become higher than that in $L$.

Ordinarily, the ice from $L$ could seed the supercooled water in $R$, but if the neck 


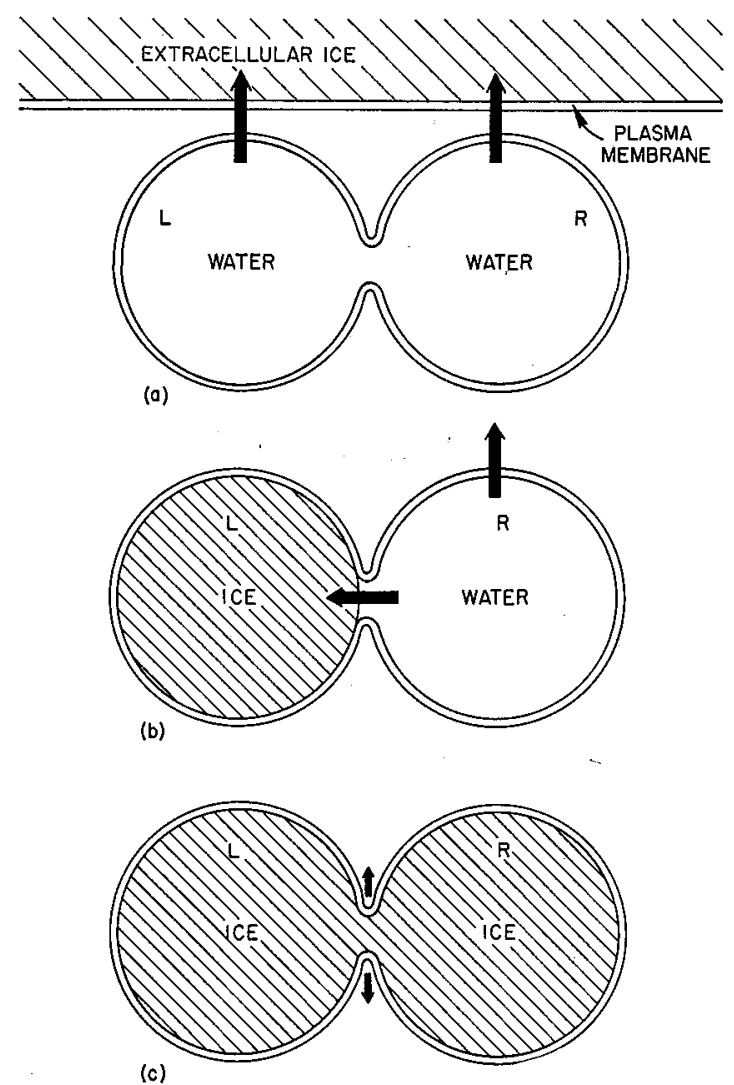

Fig. 7. Hypothetical events occurring in an intracellular compartment during freezing. See text for details

region is sufficiently narrow (10-30 $\AA$ in diameter), growth of ice through the neck into $R$ cannot occur at moderate subzero temperatures. It cannot occur because an ice crystal sufficiently small to pass through the opening would have its melting point depressed according to the equation

$$
\Delta T \approx \frac{300}{r}
$$

where $r$ is the radius of curvature in angstroms. The Kelvin equation (eq. 2) provides the basis of this curvature effect, which has been discussed elsewhere (Mazur, $1965 \mathrm{~b}$ ).

If the ice is unable to pass from $L$ to $R$ in response to the vapor pressure differential, then water will tend to move from $R$ to $L$ and freeze in $L$. Compartment $L$ will thus grow, and if it grows sufficiently, the surrounding membrane could be ruptured (Fig. 7b). This very process has been shown to be the cause of frost heaves in clay soils (Jackson and Chalmers, 1958 ; Everett, 1961).

(3) The third possibility (Fig. 7c) is for the water in both $L$ and $R$ to freeze at nearly the same time, in which case, compartment $L$ would not grow at the expense of $R$. But note that there would then be two volumes of ice with positive curvature connected by an ice neck with negative curvature. As mentioned, this situation is thermodynamically 
unstable; and given appropriate temperatures and time, water will tend to move from $L$ and $\mathrm{R}$ to the neck, increasing its diameter and the absolute value of its radius of curvature. If this process occurs, it could conceivably rupture the membrane that surrounds the neck.

Kuhn (1956) has calculated the force that would be exerted in a situation analogous to this. He considered the case of a cube of ice with a groove running around the outer surface (Fig. 8). Because of the curvature effects discussed, the groove would tend to fill in, and in so doing would exert a force on a macromolecular filament lying in the groove. For a groove $100 \times 100 \AA$, the tensile stress on the

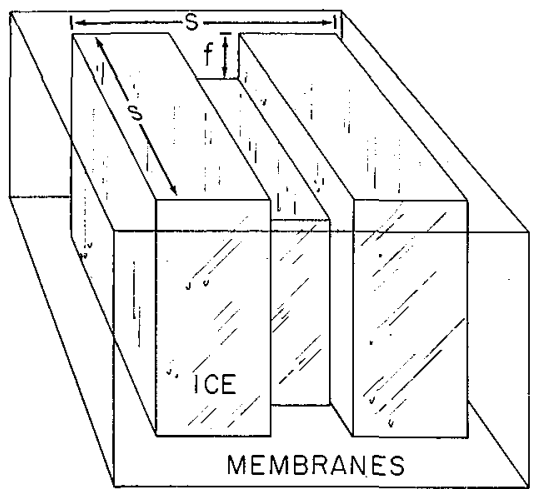

Fig. 8. Schematic drawing of a grooved cube of ice with a macromolecular filament lying in the groove. See text (from Mazur, 1966 b) filament could be as much as $8 \times 10^{6}$ dynes $/ \mathrm{cm}^{2}$ (Mazur, $1966 \mathrm{~b}$ ).

If the cross-linking of a gel is sufficiently strong, even forces of this magnitude might not be able to rupture the filaments, and ice formation would then be restricted to intragel micelles. The resulting microcrystals would be expected to have their freezing points reduced in accordance with the Kelvin equation. In support of this, Bloch, Walters and Kuhn (1963) have observed depressed freezing points in strongly cross-linked gels such as those formed from a mixture of polyacrylic acid and polyvinyl alcohol, but not in weakly cross-linked gels such as gelatin and vertebrate muscle. However, the melting point of the strongly-linked gels is normal, a finding that indicates that during the latter stages of freezing, or during warming, the microcrystals break the cross-links and fuse to form macrocrystals with normal melting points.

This model can account for the observed effects of warming velocity: Slow warming would be detrimental because it permits time for the growth of certain portions of ice crystals at the expense of others; rapid warming would be beneficial because it would result in the ice crystals melting before any recrystallization could occur.

The evidence bearing on this proposal may be summarized as follows. Kingery (1960) has observed that when two spheres of ice are brought into contact, the neck region does increase in diameter at a temperature-dependent rate. For example, with 2-mmdiameter spheres, the neck diameter increased from 0 to $0.2 \mathrm{~mm}$ in $1 \mathrm{~min}$ at $-2^{\circ} \mathrm{C}$ and in $100 \mathrm{~min}$ at $-25^{\circ} \mathrm{C}$. In still smaller spheres, the rate of neck growth was considerably higher.

There is a good deal of other evidence that ice crystals in water, aqueous solutions, and biological systems tend to increase their radii of curvature by recrystallization processes of various sorts. Meryman (1957) has demonstrated the rapid transformation of small, pure ice crystals to large ones at temperatures as low as $-96^{\circ} \mathrm{C}$. Persidsky and Luyet (1959) and Rapatz and Luyet (1959 a) have observed the enlargement of ice crystals when rapidly cooled solutions of gelatin are warmed to -10 to $-30^{\circ} \mathrm{C}$. Rapatz and Luyet (1959 b) and Menz and Luyet (1961) observed that when muscle fibers that had been cooled rapidly to $-150^{\circ} \mathrm{C}$ were warmed to $-15^{\circ} \mathrm{C}$ for $1 \mathrm{~min}$ before being recooled 


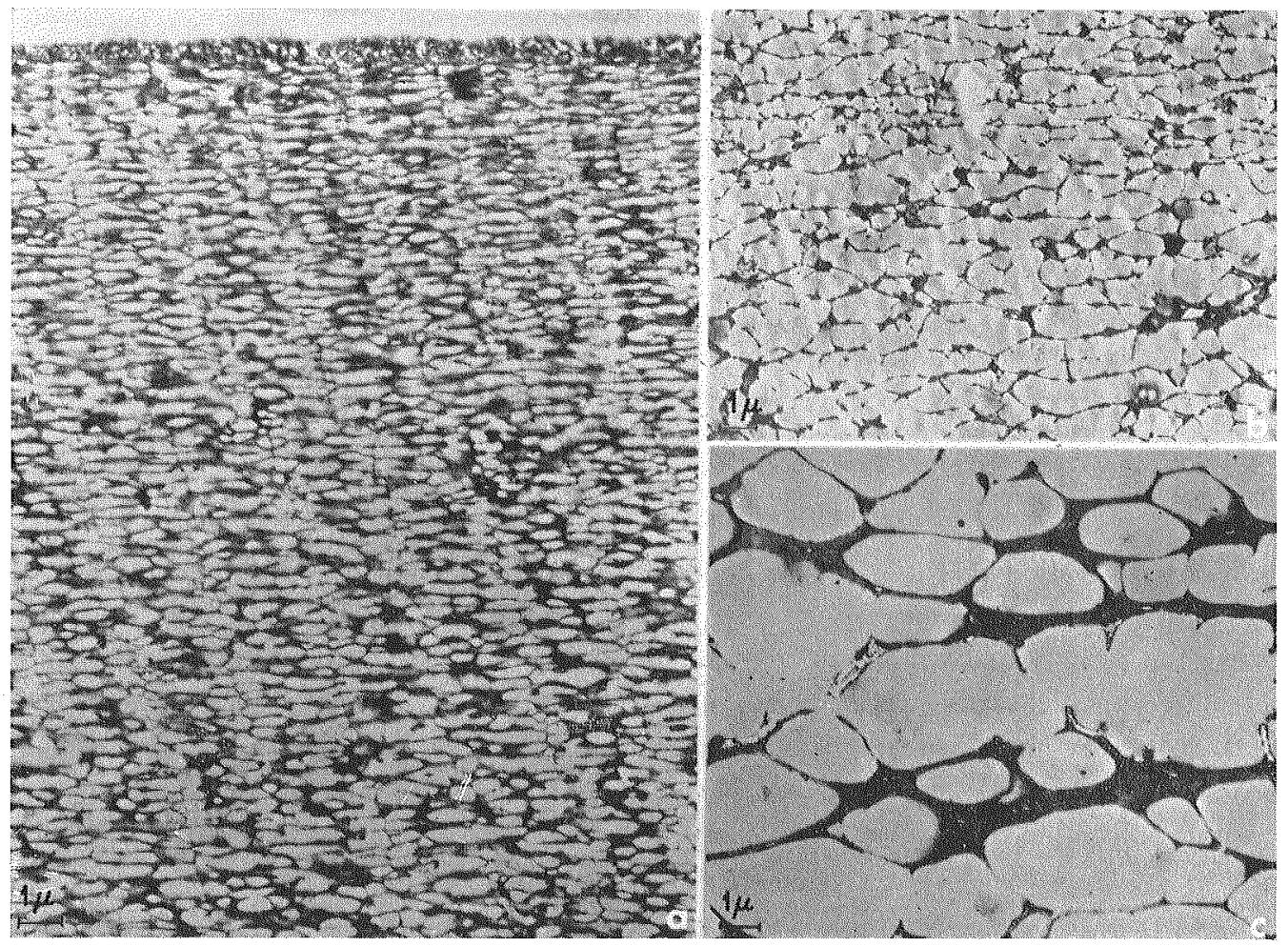

Fig. 9. Electron micrographs of frozen-dried muscle fibers, a, fiber frozen rapidly to $-190^{\circ} \mathrm{C}$ and freeze-dried at $-70^{\circ} \mathrm{C} ; b$, fiber frozen at a moderate rate to $-60^{\circ} \mathrm{C}$ and freeze-dried at $-60^{\circ} \mathrm{C}$; c, fiber frozen rapidly to $-150^{\circ} \mathrm{C}$, warmed to $-15^{\circ} \mathrm{C}$ for $1 \mathrm{~min}$, and then freeze-dried at $-60^{\circ} \mathrm{C}$ (from Menz and Luyet, 1961)

and fixed, the ice crystals grew from the size shown in Fig. 9 a to that in Fig. $9 \mathrm{c}$. Ice crystal grain growth has also been observed in frog red blood cells (Rapatz and Luyet, 1960,1961 ), and in chick fibroblasts (Rey, 1957) that had been cooled rapidly to below $-70^{\circ} \mathrm{C}$ and then warmed to about $-20^{\circ} \mathrm{C}$. Finally, a number of investigators have noted that when cells freeze intracellularly, they suddenly become opaque, indicating that they are either filled by many small ice crystals or by a few highly branched crystals. After a few minutes, however, the cells become more transparent, an observation that suggests that the small crystals have either fused into fewer large ones, or that the highly branched portions of the crystals with their small radii of curvature have become less branched, and the crystals more spherical (Chambers and Hale, 1932; Asahina, 1956).

To summarize, the survival of yeast cells that are cooled at rates sufficiently high to induce intracellular ice is markedly affected by the rates at which the cells are permitted to warm; rapid warming yields a much higher percentage survival than slow warming. Slow warming at comparable rates is also known to result in an increase in the absolute radius of curvature of ice crystals in cells. This increase is a result of increased crystal size and perhaps of decreased branching. The correlation suggests that injury may be caused by changes in crystal size or form which lead to destruction of structural components of the cell. 
Table 2. Alterations in frozen-thawed yeast cells

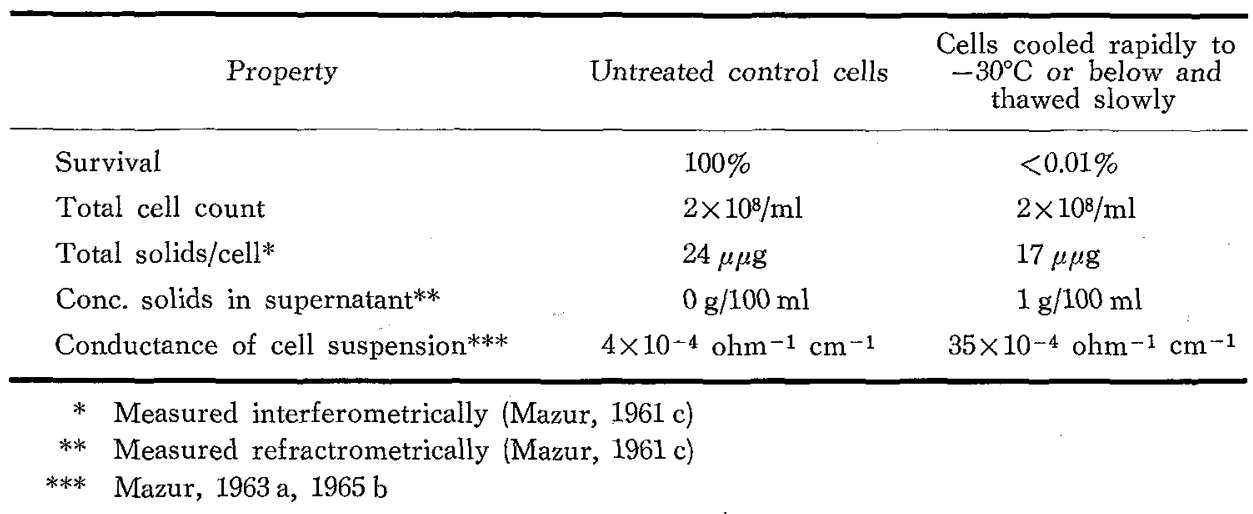

The suggestion that it is the structural elements of the cell that are directly affected by intracellular ice is supported by two observations. One is that unlike yeast cell viability, the activity and conformation of soluble proteins appear to be quite insensitive to rapid freezing (Hanafusa, 1962; Shikama, 1963; Chilson et al., 1965). The other is that yeast cells that are killed by freezing and thawing are found to have suffered extensive membrane damage as evidenced by the loss of intracellular solutes (Table 2), increased membrane conductivity (Mazur, $1963 \mathrm{a}, 1965 \mathrm{~b}$ ) and increased permeation by exogenous solutes (Souzu, 1965; Araki, 1965). It has not been possible to prove that the membrane damage is caused by intracellular ice, but conductivity measurements on frozen suspensions indicate that the damage is present even before the suspensions have thawed (Mazur, $1963 \mathrm{a}, 1965 \mathrm{~b})$.

\section{Conclusions}

Although the entire discussion has been concerned with the mechanism of injury by intracellular freezing, it must be stressed that intracellular ice is not the only lethal factor in yeast. It was seen in Figs. 1 and 2 that regardless of the cooling rate and warming rate, the maximum survival obtainable in cells cooled to $-196^{\circ} \mathrm{C}$ is about $50-60 \%$. Presumably, the other $40-50 \%$ are killed by some factor other than intracellular ice-perhaps solute concentration or the removal of water.

But when survival drops far below $50 \%$, as it does after rapid cooling and slow warming, the additional lethality is believed to be due chiefly to the formation of intracellular ice.

Many other cells, of course, are injured by freezing and thawing with usual laboratory procedures, but without the sort of analysis described here one cannot arbitrarily assume the injury is due to intracellular freezing. On the other hand, if the conclusion that intracellular freezing is caused by failure of a cell to dehydrate osmotically during cooling is correct, then all cells should be capable of freezing internally. However, as has been pointed out elsewhere (Mazur, $1963 \mathrm{~b}, 1965 \mathrm{a}, 1966 \mathrm{a}$ ), the cooling rates required for internal freezing may vary from $0.05^{\circ} \mathrm{C} / \mathrm{min}$ for very large impermeable cells or tissues to $3000^{\circ} \mathrm{C} / \mathrm{min}$ for small highly permeable cells like human erythrocytes.

The cause or causes of the lethality of intracellular freezing remain uncertain. I 
have argued that in yeast the cause is not the removal of water, but may be membrane damage resulting from changes in the curvature of the ice crystals. The hypothesis remains to be proved. If it is basically correct, one wonders whether certain organelles are affected more than others, and one wonders how the destruction or disruption is related to the three-dimensional structure of the structural component and its interaction with water at normal temperatures.

\section{Acknowledgments}

The careful work of Mrs. Janice J. Schmidt which led to the data in Figs. 1, 2, 5 and 6 is gratefully acknowledged.

\section{References}

ARAKI, T. 1965 The effect of freeze-thawing upon the fermentation of yeast cells. Low Temp. Sci., B 23, 97-109.*

ARAKI, T. and NEI, T. 1962 The mechanism of freezing in micro-organisms. I. Factors affecting the survival of yeast cells subjected to subzero temperatures. Low Temp. Sci., B 20, $57-68 . *$

Asahina, E. 1956 The freezing process of plant cell. Contr. Inst. Low Temp. Sci., 10, 83-126.

ASAHINA, E. 1961 Intracellular freezing and frost resistance in egg cells of the sea urchin. Nature, 191, 1263-1265.

Asaitina, E. 1962 Frost injury in living cells. Nature, 196, 445-446.

Asahina, E. 1965 Freezing process and injury in isolated animal cells. Fed. Proc., 24, Suppl. 15, S-183-187.

BLOCH, R., WALTERS, D. H. and KUHN, W. 1963 Structurally caused freezing point depression of biological tissues. J. Gen. Physiol., 46, 605-615.

Chambers, R. and Hale, H. P. 1932 The formation of ice in protoplasm. Proc. Roy. Soc., B 110, 336-352.

Chilson, O. P., Costelio, L. A. and Kaplan, N. O. 1965 Effects of freezing on enzymes. Fed. Proc., 24, Suppl. 15, S-55-65.

EVERETT, D. H. 1961 The thermodynamics of frost damage to porous solids. Trans, Faraday Soc., 57, 1541-1551.

Gehenio, P. M., Rapatz, G. L. and Luyet, B. J. 1963 Effects of freezing velocities in causing or preventing hemolysis. Biodynamica, 9, 77-82.

GREAVES, R. I. N. and DAVIES, J. D. 1965 Separate effects of freezing, thawing and drying living cells. Ann. N. Y. Acad. Sci, 125, 548-558.

HanafuSA, N. 1962 Denaturation of myosin-B due to freezing and thawing. Low Temp. Sci., B 20, $81-94$.*

JACKSON, K. A. and ChALMERS, B. 1958 Freezing of liquids in porous media with special reference to frost heave in soils. J. Appl. Phys., 29, 1178-1181.

KINGERY, W. D. 1960 Regelation, surface diffusion, and ice sintering. J. Appl. Phys., 31, 833-838.

Kunn, W. 1956 Über die durch anomale Kristallgestalt sowie durch Limitierung der Kristallgrösse bedingte Gefrierpunktserniedrigung. Helv. Chim. Acta, 39, 1071-1086.

LEVITT, J. 1962 A sulfhydryl-disulfide hypothesis of frost injury and resistance in plants. J. Theoret. Biol., 3, 355-391.

Luyet, B. J., Rapatz, G. L. and Gehenio, P. M. 1963 On the mode of action of rapid cooling 
in the preservation of erythrocytes in frozen blood. Biodynamica, 9, 95-124.

MAzUR, P. 1961 a Physical and temporal factors involved in the death of yeast at subzero temperatures. Biophys. J., 1, 247-264.

MazUR, P. $1961 \mathrm{~b}$ Manifestations of injury in yeast cells exposed to subzero temperatures. I. Morphological changes in freeze-substituted and in "frozen-thawed" cells. J. Bacteriol., 82, 662-672.

MAZUR, P. 1961 c Manifestations of injury in yeast cells exposed to subzero temperatures. II. Changes in specific gravity and in the concentration and quantity of cell solids. $J$. Bacteriol, 82, 673-684.

MAZUR, P. 1963 a Studies on rapidly frozen suspensions of yeast cells by differential thermal analysis and conductometry. Biophys. J., 3, 323-353.

MAzUR, P. $1963 \mathrm{~b}$ Kinetics of water loss from cells at subzero temperatures and the likelihood of intracellular freezing. J. Gen. Physiol., 47, 347-369.

MAzUR, P. 1965 a Causes of injury in frozen and thawed cells. Fed. Proc., 24, Suppl. 15, S-175-182.

MAZUR, P. $1965 \mathrm{~b}$ The role of cell membranes in the freezing of yeast and other single cells. Ann. N. Y. Acad. Sci, 125, 658-676.

MAZUR, P. 1966 a Theoretical and experimental effects of cooling and warming velocity on the survival of frozen and thawed cells. Cryobiology, 2, 181-192.

MAzUR, P. $1966 \mathrm{~b}$ Physical and chemical basis of injury in single-celled microorganisms subjected to freezing and thawing. In Cryobiology (H. T. MERYMAN, ed.), Academic Press, London, 813-315.

MENZ, L. J. and LUYET, B. J. 1961 An electron microscope study of the distribution of ice in single muscle fibers frozen rapidly. Biodynamica, 8, 261-294.

Meryman, H. T. 1957 Physical limitations of the rapid freezing method. Proc. Roy. Soc., B 147, $452-459$.

Meynel.L, G. G. 1958 The effect of sudden chilling on Escherichia coli. J. Gen. Microbiol., 19, 380-389.

NEI, T. 1960 Effects of freezing and freeze-drying on microorganisms. In Recent Research in Freezing and Drying (A. S. PARKEs and A. U. SMITH, eds.), Blackwell Scientific Publications, Oxford, 78-86.

PERSIDSKY, M. D. and LUYET, B. J. 1959 Low temperature recrystallization in gelatin gels and its relationship to concentration. Biodynamica, 8, 107-120

RAPATZ, G. and LUYET, B. 1959 a Recrystallization at high subzero temperatures in gelatin gels subjected to various cooling treatments. Biodynamica, 8, 85-105.

RAPATZ, G. and LUYET, B. $1959 \mathrm{~b}$ On the mechanism of ice formation and propagation in muscle. Biodynamica, 8, 121-144.

RAPATZ, G. and LUYET, B. 1960 Microscopic observations on the development of the ice phase in the freezing of blood. Biodynamica, 8, 195-239.

RAPATZ, G. and LUYET, B. 1961 Electron microscope study of erythrocytes in rapidly frozen frog's blood. Biodynamica, 8, 295-315.

RAPATZ, G., NATH, J. and LUYET, B. J, 1963 Electron microscope study of erythrocytes in rapidly frozen mammalian blood. Biodynamica, 9, 83-94.

REY, L. R. 1957 Studies on the action of liquid nitrogen on cultures in vitro of fibroblasts. Proc. Roy. Soc., B 147, 460-466.

REY, L. R. 1960 Thermal analysis of eutectics in freezing solutions. Ann. N. Y. Acad. Sci., 85, 510-534,

SANT, R. K. and PETERson, W. H. 1958 Factors affecting loss of nitrogen and fermenting power of rehydrated active dry yeast. Food Technol., 12, 359-362.

ShERMAN, J. K. 1962 Survival of higher animal cells after the formation and dissolution of intra- 
cellular ice. Anat. Rec., 144, 171-190.

ShIKAMA, K. 1963 Denaturation of catalase and myosin by freezing and thawing. Sci. Rep. Tôhoku Univ., Ser. IV (Biol.), 29, 91-106.

SMITH, A. U. 1961 Biological Effects of Freezing and Supercooling. Monographs of the Physiological Society, Number 9. Williams and Wilkins Co., Baltimore, Md., 440 pp.

SouzU, H. 1965 Freezing injury in yeast cells. Outbreak of phosphatase activity by freeze-thawing. Low Temp. Sci., B 23, 85-96.*

SouzU, H., NEI, T. and BrTo, M. 1961 Water of microorganisms and its freezing. With special reference to the relation between water content and viability of yeast and coli cells. Low Temp. Sci., B 19,49-57.*

Wood, T. H. and Rosenberg, A. M. 1957 Freezing in yeast cells. Biochim. Biophys. Acta, 25, $78-87$.

* In Japanese with English summary. 